\title{
Preparation of Activated Carbons From Banana (Musa acuminate L.) peels for Carbon Monoxide Adsorption
}

Vera Viena, Elvitriana and Muhammad Nizar

Environmental Engineering Department, Serambi Mekkah University, Banda Aceh, Indonesia

Sari Wardani

Faculty of Agriculture, Abulyatama University, Aceh Besar, Indonesia

Suhendrayatna

Faculty of Engineering, Chemical Engineering Department, Syiah Kuala

University, Banda Aceh, Indonesia

\begin{abstract}
Purpose - In this research, we have prepared activated carbon (AC) from the waste of banana peels (Musa acuminate L.) using potassium hydroxide ( $\mathrm{KOH})$ for carbon monoxide $(\mathrm{CO})$ adsorption from motorcycle gas emission.

Design/Methodology/Approach - The activation was conducted using a chemical activator $(\mathrm{KOH})$ at various concentrations of 1,2 , and $3 \mathrm{~N}$ for 1,2 , and $3 \mathrm{~h}$, respectively. Characteristics of banana peels $\mathrm{AC}$ (BPAC) produced were analyzed using the Fourier-transform infra-red spectroscopy and scanning electron microscopy.

Findings - Results showed that $\mathrm{KOH}$ concentration and activation time strongly affected the $\mathrm{CO}$ adsorption and opening of the $\mathrm{AC}$ surface pore. There was an increase in the $\mathrm{CO}$ sorption when the $\mathrm{KOH}$ concentration was increased up to $3 \mathrm{~N}$ concentration. The highest $\mathrm{CO}$ adsorption from the emission occurred at $70.95 \%$ under $\mathrm{KOH}$ concentration of $3 \mathrm{~N}$ during the 3 -h preparation.

Research Limitations/Implications - BPAC has been used as an adsorbent for only CO from motorcycle gas emission but not as an adsorbent for $\mathrm{HC}, \mathrm{NO}, \mathrm{NO}_{\mathrm{x}}$, or $\mathrm{H}_{2} \mathrm{~S}$.

Practical Implications - BPAC can be used as the potential adsorbent for the removal of $\mathrm{CO}$ from motorcycle gas emission, and it is an environmental friendly, low cost, and easy to make adsorbent.

Originality/Value - In this study, the AC is made from biomass and is used in wastewater treatment, but limited studies are found on the removal of $\mathrm{CO}$ from motorcycle gas emission.
\end{abstract}

Keywords Banana peels activated carbon, $\mathrm{KOH}$, adsorbent, Carbon monoxide

The researcher acknowledges the Indonesian Ministry of Research, Technology and Higher Education for funding this study using DIPA 2017.

(C) Vera Viena, Elvitriana, Muhammad Nizar, Sari Wardani, Suhendrayatna. Published in the Emerald Reach Proceedings Series. Published by Emerald Publishing Limited. This article is published under the Creative Commons Attribution (CC BY 4.0) licence. Anyone may reproduce, distribute, translate and create derivative works of this article (for both commercial and noncommercial purposes), subject to full attribution to the original publication and authors. The full terms of this licence may be seen at http://creativecommons.org/licences/by/4.0/legalcode

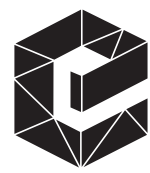

Emerald Reach Proceedings Series Vol. 1 pp. 381-386 
All papers within this proceedings volume have been peer reviewed by the scientific committee of the Malikussaleh International Conference on Multidisciplinary Studies (MICoMS 2017).

\section{Introduction}

Activated carbon (AC) is a porous solid containing 85-95\% carbon. Materials containing carbon can produce AC by heating them at high temperature. Pores could function as an adsorbent of carbon. AC with a bulky surface area has been used for various purposes, such as color remover, reliever, deodorizing agent, and purifying agent in the food industry. It is also commonly used in the water purification process - both in the production of drinking water and in the wastewater treatment (Wu, 2004). The advantages of AC prepared using agricultural by-products offered an effective, inexpensive replacement for non-renewable coalbased granular ACs, which has similar or better adsorption efficiency (Martin et al., 2003).

The exploitation of alternative waste materials from industry and agriculture for AC production has been encouraged in the recent years (Kadirvelu and Namasivayam, 2003). Some studies showed that the banana peels contained polyphenols, carotenoids and other bioactive compounds that have many advantages for human health (Larrauri et al., 1999). The potential applications of banana peels vary based on its chemical composition. It is composed of dietary fiber, proteins, essential amino acids, polyunsaturated fatty acids, and potassium (Emaga et al., 2007).

Giraldo and Morena-Pirajan (2014) mentioned that in the past five decades, industrialization has deflated and polluted the planet because of the uncontrolled usage of fossil fuels as the main energy source; consequently, the average global temperature has increased, thereby altering the ecosystem. In particular, according to Castro et al. (2001), the internal combustion engine in the industry has become one of the major causes of environmental pollution with their excess gas emission, such as $\mathrm{CO}_{2}, \mathrm{CO}$, hydrocarbons, $\mathrm{SO}_{2}$, and $\mathrm{NO}_{x}$, generating volatile organic compounds (VOC) and particulate matter. This factor contributed to the greenhouse effect, acid rain, photochemical smog, stratospheric ozone depletion, and the global warming.

To reduce these emissions, some studies had suggested the usage of porous materials such as mesoporous materials, modified mesoporous materials, alumina, silicon compounds, compounds derived from coal as both chemically and physically activated powders, granular materials, and fabrics modified with $\mathrm{TiO}_{2}$. Castro et al. (2011) identified functional groups of $\mathrm{OH}$, $-\mathrm{COO}$, and $-\mathrm{NH}$ in the banana peel and stated that these organic compounds serve as an adsorbent and had abundant potential to be made as one of the low-cost biomass ACs through physical and chemical activation. Mopoung et al. (2015) studied the removal of Fe from the aqueous solution by AC prepared from tamarind seeds by potassium hydroxide $(\mathrm{KOH})$ activation. The percentage yield was highly affected by the activation temperature and $\mathrm{KOH}$-seed ratio. The infra-red spectra characterized on the $\mathrm{AC}$ surface showed the following functional groups: $\mathrm{O}-\mathrm{H}, \mathrm{C}=\mathrm{O}, \mathrm{C}-\mathrm{O},-\mathrm{CO}_{3}, \mathrm{C}-\mathrm{H}$, and $\mathrm{Si}-\mathrm{H}$.

Sugumuran et al. (2012) also studied the chemical activation using $\mathrm{H}_{3} \mathrm{PO}_{4}$ and $\mathrm{KOH}$ in the preparation of ACs from the pyrolysis of banana empty fruit bunch waste and fruit pods of Delonix regia at $450^{\circ} \mathrm{C}$ and $400^{\circ} \mathrm{C}$. The yields of the ACs produced using chemical activation were found to be more qualified than untreated carbon. The ACs produced had an improved adsorption characteristics such as surface area, chemical functional groups, and the ability to remove iodine and methylene blue when compared with the high-performance adsorbents.

Until now, there is a limited literature on the utilization of $\mathrm{KOH} \mathrm{AC}$ for the adsorption of carbon monoxide (CO) from gas emission. Ultimately, the carbon produced is used for the removal of heavy metal from the wastewater or for water purification. In this research, the 
AC was prepared from the waste of banana peels (Musa acuminate L.) for CO adsorption from motorcycle gas emission. Characteristics of banana peels AC (BPAC) produced were compared with the Indonesian National Standard Quality (SNI no. 06-3730-1995). Characterization was conducted using an approximate method, whereas surface analysis of the AC was performed using the Fourier-transform infra-red (FTIR) spectroscopy and scanning electron microscopy (SEM) to examine the CO adsorption capacity from motorcycle gas emission.

\section{Materials and method}

\subsection{Materials}

Banana peel waste was collected from Banda Aceh traditional market. Chemicals such as $\mathrm{KOH}$, iodine, natrium thiosulfate, and amilum powder were purchased from Merck, p.a. grade.

\subsection{Research procedure}

2.2.1. Preparation of $B P A C$ Banana peel was cut into pieces of $\pm 3 \mathrm{~cm}$ and dried in the oven. The dried peels were carbonized in the furnace (Line Thermocline FB1410M-33) at a temperature of $400^{\circ} \mathrm{C}$ for $1.5 \mathrm{~h}$. Carbon was mashed and sifted using 100-mesh sieves. Carbon was activated chemically using $\mathrm{KOH}$ at various concentrations of 1,2 , and $3 \mathrm{~N}$ for 1 , 2 , and $3 \mathrm{~h}$, respectively. Carbon was filtered and washed thoroughly with aquadest until neutral $\mathrm{pH}$ was reached and then heated at $200^{\circ} \mathrm{C}$ for $2 \mathrm{~h}$. The BPAC produced was then mixed with adhesive and molded to attain a size of $1 \mathrm{~cm}$ in length, $1 \mathrm{~cm}$ in width, and $1 \mathrm{~cm}$ in height. After hardening, the BPAC was heated in an oven for $3 \mathrm{~h}$ at $120^{\circ} \mathrm{C}$.

2.2.2. Characteristic Analysis of BPAC The characteristics of BPAC were analyzed using the proximate analysis that consisted of water content, ash content, volatile matter, fixed carbon, and iodine adsorption capacity. The functional group analysis on the surface of BPAC was performed using the FTIR spectroscopy (FTIR Shimadzu Prestige-6400). The BPAC characteristics were compared with the Indonesian National Standard Quality (SNI no. 06-3730-1995). The surface and the pores of the BPAC were observed using the SEM. The motorcycle gas emission analysis was performed using the Emissions Analyzer (Sensonic-6000) for recording CO from the gas emission.

2.2.3. CO Adsorption Treatment using BPAC Measurement of CO from the motorcycle gas emission was conducted by mounting the tested vehicle in a flat position. Engine acceleration was conducted at an idle condition with an engine rotation of $800 \mathrm{rpm}$ as manufacturer's recommendation. The adsorption tube containing BPAC was connected to the vehicle's exhaust, and the $\mathrm{CO}$ from the gas emission was analyzed by the Emissions Analyzer (Sensonic-60000).

\section{Results and discussion}

\subsection{Characteristics of $B P A C$}

Table 1 presents the characteristics of BPAC before and after the activation using $\mathrm{KOH}$. The characteristics were measured by the proximate analysis that consisted of moisture content, volatile matter, ash, fixed carbon, and iodine adsorption.

\subsection{FTIR Spectroscopy Results of AC}

Figure 1 shows the FTIR spectrum of raw banana peel carbon (BPC). Bands in the region of 3,612 and 3,124 cm $\mathrm{cm}^{-1}$ were assigned to $\mathrm{O}-\mathrm{H}$ stretching, and those at 2,892 and 2,920 $\mathrm{cm}^{-1}$ were assigned to $\mathrm{C}-\mathrm{H}$ stretching. The FTIR analysis results indicate only a slight difference 


\begin{tabular}{|c|c|c|c|c|c|c|c|c|}
\hline \multirow[t]{4}{*}{$\begin{array}{l}\text { Proceedings of } \\
\text { MICoMS } 2017\end{array}$} & No. & $\begin{array}{c}\text { Activation } \\
\text { Concentration }\end{array}$ & $\begin{array}{l}\text { Activation Time } \\
\text { (hours) }\end{array}$ & $\begin{array}{c}\text { Moisture } \\
\text { Content (\%) }\end{array}$ & $\begin{array}{c}\text { Volatile } \\
\text { Matter (\%) }\end{array}$ & $\begin{array}{l}\text { Ash } \\
(\%)\end{array}$ & $\begin{array}{c}\text { Fixed } \\
\text { Carbon (\%) }\end{array}$ & $\begin{array}{l}\text { Iodine Adsorption } \\
\qquad(\mathrm{mg} / \mathrm{g})\end{array}$ \\
\hline & 1 & No activation & - & 9,360 & 9,360 & 7,700 & 73,580 & 659,880 \\
\hline & 2 & KOH $1 \mathrm{~N}$ & 1 & 8,361 & 8,361 & 7,000 & 76,278 & 761,400 \\
\hline & 3 & $\mathrm{KOH} 1 \mathrm{~N}$ & 2 & 6,020 & 6,020 & 7,100 & 80,860 & 789,318 \\
\hline \multirow{6}{*}{384} & 4 & $\mathrm{KOH} 1 \mathrm{~N}$ & 3 & 5,017 & 5,017 & 7,500 & 82,467 & 819,774 \\
\hline & 5 & $\mathrm{KOH} 2 \mathrm{~N}$ & 1 & 5,686 & 5,686 & 8,300 & 80,329 & 789,318 \\
\hline & 6 & $\mathrm{KOH} 2 \mathrm{~N}$ & 2 & 10,033 & 10,033 & 8,900 & 71,033 & 818,505 \\
\hline & 7 & $\mathrm{KOH} 2 \mathrm{~N}$ & 3 & 9,365 & 9,365 & 9,700 & 71,571 & 845,154 \\
\hline & 8 & $\mathrm{KOH} 3 \mathrm{~N}$ & 1 & 3,679 & 3,679 & 10,400 & 82,242 & 817,236 \\
\hline & 9 & KOH $3 \mathrm{~N}$ & 2 & 2,007 & 2,007 & 10,110 & 85,877 & 837,540 \\
\hline Table 1. & 10 & KOH 3 N & 3 & 12,375 & 12,375 & 11,120 & 64,131 & 862,920 \\
\hline Characteristics of AC & & Indonesian Nat & tional Standard & $\operatorname{Max} 15$ & $\operatorname{Max} 25$ & $\operatorname{Max} 10$ & Min 65 & Min 750 \\
\hline
\end{tabular}

between samples that could be established. However, the shift in bands and the changes in the number of wavelengths and adsorbance between the unactivated and activated samples indicate that chemical transformation has occurred during chemical treatment or pyrolysis.

\subsection{Results of the SEM Analysis}

Figure 2 shows the SEM images of raw $\mathrm{BPC}$ and treatment variations of $\mathrm{BPAC}$ with $\mathrm{KOH}$. $\mathrm{BPC}$ showed a more uniform opening pore when compared with the $\mathrm{KOH} \mathrm{AC} \mathrm{(Figure} \mathrm{2B-D).}$ The increase in the $\mathrm{KOH}$ concentration closed the surface of the active carbon pore. In addition, the release of potassium at the time of activation process also played a role in covering the part of the pore of $\mathrm{AC}$, so that iodine uptake in $\mathrm{KOH} \mathrm{AC}$ was lower with an increase in concentration of $\mathrm{KOH}$. In Figure $2 \mathrm{C}$ and $\mathrm{D}$, the formation of small crystals of potassium is shown, which also can indirectly inhibit the adsorption process. The SEM image revealed that the pore of $\mathrm{KOH} \mathrm{AC}$ was not fully open, and, hence, the ability of $\mathrm{CO}$ emission adsorption was low. These results suggested that $\mathrm{KOH}$ concentration and activation time strongly affected the $\mathrm{CO}$ adsorption.

\subsection{The effect of $\mathrm{KOH} A \mathrm{C}$ onto the $\mathrm{CO}$ Emission Adsorption}

The effect of $\mathrm{KOH} \mathrm{AC}$ onto $\mathrm{CO}$ emission adsorption was studied using different $\mathrm{KOH}$ concentration from 1 to $3 \mathrm{~N}$. The sorption of $\mathrm{CO}$ increased by increasing $\mathrm{KOH}$, as an activator, concentration up to $3 \mathrm{~N}$. The adsorption of $\mathrm{CO}$ from the emission occurred to a

Figure 1.

Wavelength of the FTIR Spectra for the BPAC Adsorbent

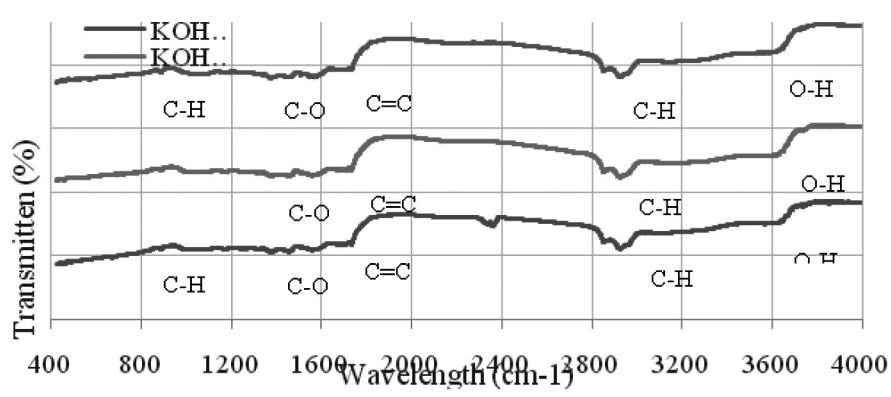



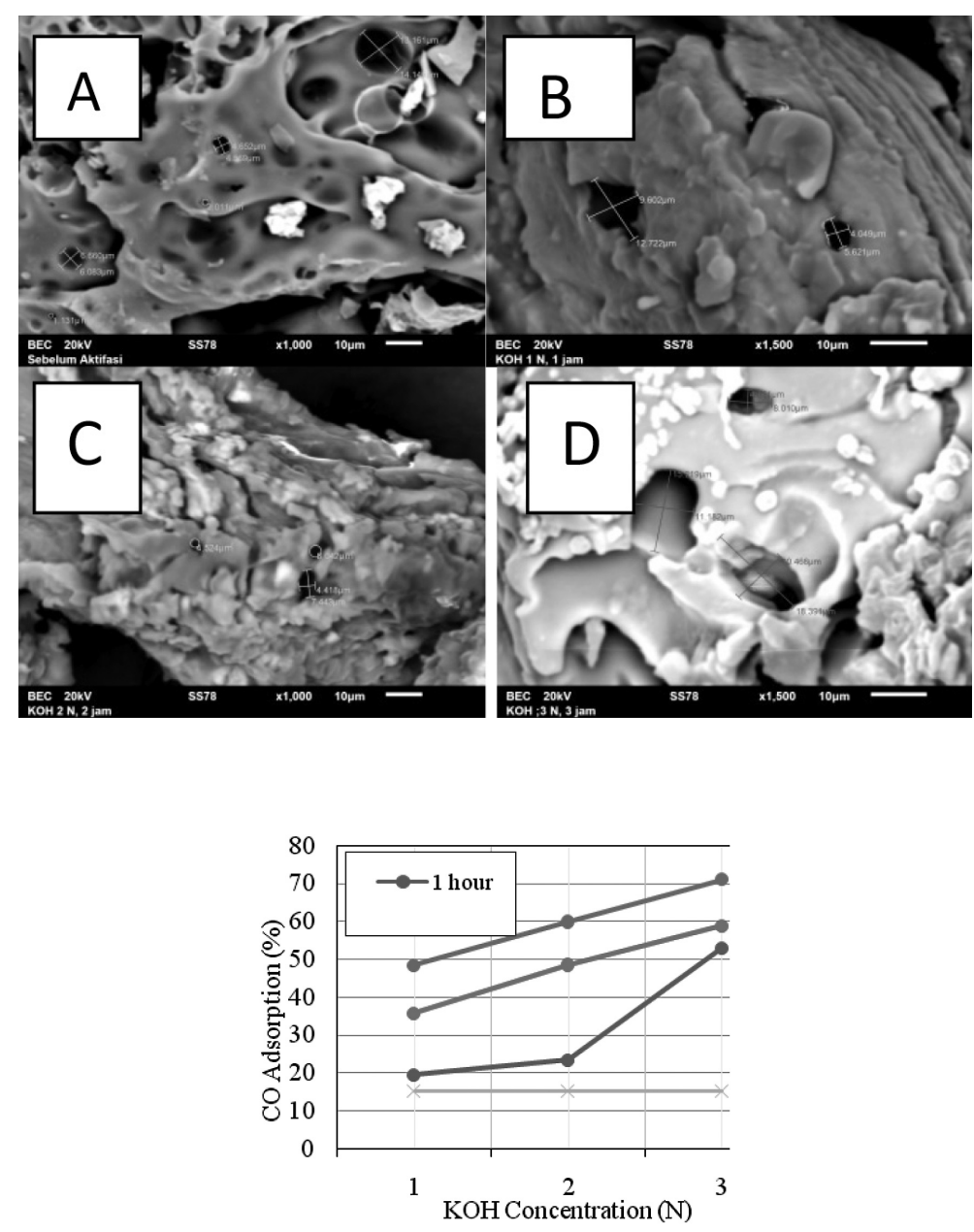

maximum of $70.95 \%$ under $\mathrm{KOH}$ concentration $3 \mathrm{~N}$ during the 3 -h preparation. This result is indicates that the concentration of activator increases the surface area. The research by Sugumaran $e t$ al. (2012) added that activation time will affect the amount of CO adsorption from the emission. The adsorption of $\mathrm{CO}$ gas was increased by increasing the activation time to $3 \mathrm{~h}$. It was revealed that the concentration of $\mathrm{KOH}$ of $3 \mathrm{~N}$ for 3 -h activation as activator would be suitable for preparing the BPAC as an adsorbent. These results proved that $\mathrm{BPAC}$ was able to adsorp $\mathrm{CO}$ emissions, and it is the potential alternative adsorbent for removing air pollutants from motorcycle gas emission in the future (Figure 3).

\section{Conclusions}

$\mathrm{BPAC}$ has the potential to be used as an adsorbent for the removal of $\mathrm{CO}$ from motorcycle gas emission. The SEM images suggested that $\mathrm{KOH}$ concentration and activation time
BPAC for CO Adsorption

385

Figure 2. The SEM of KOH AC.

(A) No activation, BPC; (B) KOH $1 \mathrm{~N}$ for

$1 \mathrm{~h}$; (C) $\mathrm{KOH} 2 \mathrm{~N}$ for $2 \mathrm{~h}$; and (D) $\mathrm{KOH} 3 \mathrm{~N}$ for $3 \mathrm{~h}$

Figure 3.

The effect of KOH AC onto the COEmission Adsorption 
Proceedings of MICoMS 2017 strongly affected the $\mathrm{CO}$ adsorption and opening of $\mathrm{AC}$ surface pore. The sorption of $\mathrm{CO}$ increased when the $\mathrm{KOH}$ concentration increased up to $3 \mathrm{~N}$. The highest $\mathrm{CO}$ adsorption from the emission occurred at $70.95 \%$ under the $\mathrm{KOH}$ concentration of $3 \mathrm{~N}$ during $3-\mathrm{h}$ preparation.

\section{References}

Castro, T., Madronich, S., Rivale, S., Muhlia, A. and Mar, B. (2001). "The Influence of Aerosols on Photochemical Smog in México City”. Atmospheric Environment, Vol. 35, pp. 1765-1772.

Castro, G., Caetano, L., Ferreira, G., Padilha, P., Margarida, J., Zara, F. and Antonio, M. (2011). "Banana Peel Applied to the Solid Phase Extraction of Copper and Lead from River Water: Preconcentration of Metal Ions with a Fruit Waste". Journal of American Chemical Society, Vol. 50, pp. 3446-3451.

Emaga, T.H., Andrianaivo, R.H., Wathelet, B. and Tchango, J.T. (2007). "Paquot M. Effects of the Stage of Maturation and Varieties on the Chemical Composition of Banana and Plantain Peels". Food Chemistry, Vol. 103, pp. 590-600.

Giraldo, L. and Morena-Pirajan, J.C. (2014). "Activated Carbon Prepared from Orange Peels Coated with Titanium Oxide Nanoparticles: Characterization and Application in the Decomposition of $\mathrm{NO}_{x}$ ”. Oriental Journal of Chemistry, Vol. 30, No. 2, ISSN: 0970-020X

Kadirvelu, K. and Namasivayam, C. (2003). "Activated Carbon from Coconut Coir Pith as Metal Adsorbent: Adsorption of Cd (II) from Aqueous Solution”. Advances in Environmental Research, Vol. 7, pp. 471-478.

Larrauri, J.A., Ruperez, P. and Saura-calixto, F. (1999). "New Approaches in the Preparation of High Dietary Fibre from Fruit By-Products". Trends in Food Science and Technology, Vol. 29, pp. 729-733.

Martin, M.J., Artola, A., Balaguer, M.D. and Rigola, M. (2003). "Activated Carbons Developed from Surplus Sewage Sludge for the Removal of Dyes from Dilute Aqueous Solutions”. Chemical Engineering Journal, Vol. 94, pp. 231-239.

Mopoung, S., Moonsri. P, Palas. W. and Khumpai, S. (2015). "Characterization and Properties of Activated Carbon Prepared from Tamarind Seeds by KOH Activation for Fe(III) Adsorption from Aqueous Solution”. The Scientific World Journal, Vol. 2015, p. 9. Article ID 415961. Available: http://dx.doi.org/10.1155/2015/415961

Sugumaran, P., Priya S.V., Ravichandran, P. and Seshadri, S. (2012). "Production and Characterization of Activated Carbon from Banana Empty Fruit Bunch and Delonix Regia Fruit Pod”. Journal of Sustainable Energy \& Environment, Vol. 3, pp. 125-132.

Wu, J. (2004). "Modeling Adsorption of Organic Compounds on Activated Carbon”. In Multivariate Approach. Unema University, Sweden.

\section{Corresponding author}

Vera Viena can be contacted at veraviena@serambimekkah.ac.id 